\title{
Review
}

\section{Purse seining in India - a review}

\author{
P. PRAVIN AND B. MEENAKUMARI* \\ Krishi Anusandhan Bhawan - II, Indian Council of Agricultural Research, Pusa, New Delhi - 110 012, India \\ *National Biodiversity Authority, TICEL Bio Park, Taramani, Chennai - 600 113, Tamil Nadu, India \\ e-mail:pravinp2005@gmail.com
}

\begin{abstract}
Purse seining is one of the most efficient and advanced commercial fishing methods of recent times, used for harvesting shoaling fishes. Purse seines are surrounding nets in which the bottom of the net is closed after encircling the fish school, by a pursing line which prevents fish from escaping downwards by diving. In India, purse seining was introduced in the south-west coast in the late 1950s to harvest shoaling fishes like anchovies, sardines and mackerels. With the success of purse seining in the country, there were rapid technological changes in the purse seine fishing method and substantial increase in the number and size of both fishing craft and gear. This present review provides an insight into the developmental changes in purse seine fishing in India and highlights future strategies.
\end{abstract}

Keywords: Fishing gear, Fishing method, India, Purse seine, Ring seine

\section{Introduction}

Purse seines are a predominant type of surrounding nets, in which the bottom of the net is closed after encircling the fish school, by a pursing line which prevents fish from escaping downwards by diving (Nedlec, 1982; Brandt, 1984). Purse seining is one of the most aggressive and efficient commercial fishing methods for capture of shoaling pelagic species (Sainsbury, 1996; Ben-Yami, 1994a and 1994b) and is considered to have evolved from beach seines and lampara nets. The net can be operated from a range of vessel sizes and is either operated from one or two boats. Advances in purse seining were supported by the introduction of high tenacity synthetic twines of high specific gravity, improvements in vessel technology and gear handling equipment such as puretic power block, fish aggregation techniques and acoustic fish detection and remote sensing techniques (Sainsbury, 1996; Fyson, 1985; Hameed and Boopendranath, 2000).

\section{Introduction and diffusion of purse seining in India}

Purse seining experiments were conducted in India by the erstwhile Indo-Norwegian Project (INP) as early as 1954 (Menon, 1970; Mukundan and Hakim; 1980, Oommen, 1989). The INP conducted purse seining experiments during 1954-1985, off Kerala coast, and caught over $3300 \mathrm{t}$ of fish consisting of sardines, mackerel, tunas, carangids, anchovies, horse mackerel and silverbellies. Operations were conducted from $10.92 \mathrm{~m}$ (48 hp) vessels using $292 \mathrm{~m}$ x $26 \mathrm{~m}$ sardine purse seine; $17.5 \mathrm{~m}$ purse seiner (233 hp) using $366 \mathrm{~m}$ x $46 \mathrm{~m}$ sardine/mackerel purse seine; and $27.3 \mathrm{~m}$ purse seiner (750 hp) using $502 \mathrm{~m} \mathrm{x} 72 \mathrm{~m}$ tuna/mackerel purse seine (Oommen, 1989). Purse seining was attempted in Goa in
1957, when two Portuguese-built purse seiners of $13.5 \mathrm{~m}$ $\mathrm{L}_{\mathrm{OA}}$ were commissioned. Encouraged by their successful operations, two more purse seiners were added in 1970 (Sadanandan et al., 1975; Mathai, 1990). Purse seining for tunas was tried from research vessel R. V. Varuna in 1966 in Lakshadweep. Later in 1967, fishing vessels, R. V. Varuna and M. V. Tuna carried out purse seining with a $540 \mathrm{~m}$ purse seine in coastal waters (Silas, 1969). Six fishing vessels (10.97 m $\mathrm{L}_{\mathrm{OA}} ; 48 \mathrm{hp}$ ) conducted purse seining off Cochin along with fishing vessels, Norind-2, Samudradevi and Kalava-2 at 8-27 m depth. The M. V. Meena Anveshak carried out exploratory survey off Mangalore in the depth range of 10-30 m and M. V. Meena Ayojak operated off Goa in the depth range of 12-33 m. Further, exploratory purse seining was attempted between Cochin and Goa during 1975 to 1978 (Shanmugavelu and Pillai, 1980). Good scope for commercial purse seining was also indicated along the Karnataka coast (Jayaraj, 1978) and along Goa coast (Dhawan, 1978).

Commercial purse seining operations in the small scale mechanised sector was started in India with technical assistance from Integrated Fisheries Project, Cochin (earlier Indo-Norwegian Project), in November 1974, when a purse seine unit started functioning in Ponnani, under a Fishermen Co-operative Society (Brandt, 1984). Purse seiners displaced the traditional shore seine rampan and in course of time, the fishing spread steadily all along the south-west coast. The number of purse seiners in Kerala increased to 10 by 1979 and then rapidly rose to 60 by 1980 (Rao et al., 1982). Karnataka took the lead in introduction of purse seining, with about 120 vessels, which increased to 250 by 1979 . Commercial operation of purse seines in Goa started in 
1964 and the number of purse seiners increased to 42 by 1969 and to 225 by 1994 . The introduction of purse seine in Kerala and its operation in the traditional fishing grounds was opposed by the traditional fishermen of the state leading to conflicts between the mechanised and non-mechanised sectors (Nair and Jayaprakash, 1983), which necessitated introduction of regulations in the area of operation for different categories of fishing vessels, under Kerala Marine Fishing Regulation Act (KMFRA, 1980).

During 1982-83, the ICAR-Central Institute of Fisheries Technology (ICAR-CIFT), Kochi developed and introduced a mini purse seine, which is a lightly constructed purse seine, popularly known as ring seine (Panicker, 1985; Panicker et al., 1985) for the traditional sector, for operation from motorised boats. Both purse seines and ring seines target mostly coastal shoaling pelagic resources like anchovies, sardines and mackerels. Introduction of ring seines in Kerala revived the traditional sector substantially and reduced the dominance of purse seine considerably. Subsequently, ring seine became the most prominent fishing gear in the artisanal sector for harvesting pelagic resources in Kerala (Edwin and Hridyanathan, 1996; Joice et al., 2003). Due to conflict with the traditional fishermen coupled with the ban imposed by the Fisheries Department for operation of purse seine in the inshore areas, and decline in catch, the number of purse seiners operating in Kerala dwindled to 17 in 2004. Though mini purse seine was confined to the south-west coast of India in the beginning, it has spread to the north-west coast as well as to the east coast of India and Andaman and Nicobar Islands, in recent years (Shilader, 2009; Edwin et al., 2014).

\section{Fishing craft}

Currently, there are 1,213 purse seiners operating in India which are confined to the west coast of India, of which maximum number is in Maharashtra (435), followed by Karnataka (422), Goa (296) and Kerala (60) CMFRI (2012) (Table 1). Verghese (1976) recommended that a $10.98 \mathrm{~m}$ $\mathrm{L}_{\mathrm{OA}}$ vessel and a skiff would be the smallest vessel required for economic purse seine operations along the south-west coast of India. The overall length and horsepower of the engine of the purse seiner has increased considerably over the years. Purse seine vessels are made of wood, steel or fibre-reinforced plastic (FRP) (11 to $23 \mathrm{~m} \mathrm{~L}_{\mathrm{OA}}$ ) and equipped with 110-420 hp engines (Edwin et al., 2014).

Over the years, many electronic gadgets like echosounder, Global Positioning System (GPS), communication equipment (VHF marine transceiver and mobile phone) are increasingly used to facilitate fishing operation and navigation. Fish detecting equipment like SONAR was introduced only recently and a few boats in Goa have started using it. The present generation of fishermen are well versed in the use of these electronic gadgets for fishing and navigation. Fishing operations have switched from manual to mechanical with improved deck equipments like the mechanical or hydraulic purse seine winch, drum and gallows. Hauling of the purse line used to be by mechanised gypsy (Hameed and Asok, 1987). With increase in size and weight of the net, the power block, a hauling device for hauling the purse seine was introduced in Kerala and later in Goa for mechanised purse seiners (Pravin and Meenakumari, 2011a). Typically, there are two designs of purse seiners, one based on Indo-Norwegian design with astern deck arrangement and the other based on Portuguese design as seen in Goa and Mangalore with forward deck arrangement (Mukundan and Hakim, 1980). The general deck layout of a typical purse seiner in the country is given in Fig. 1. The wheelhouse is located in the mid-deck and the aft of the boat is used for storing the net. The purse line gallows are positioned in the port side in the mid-ship. The purse seine drum is located in the forward starboard side.

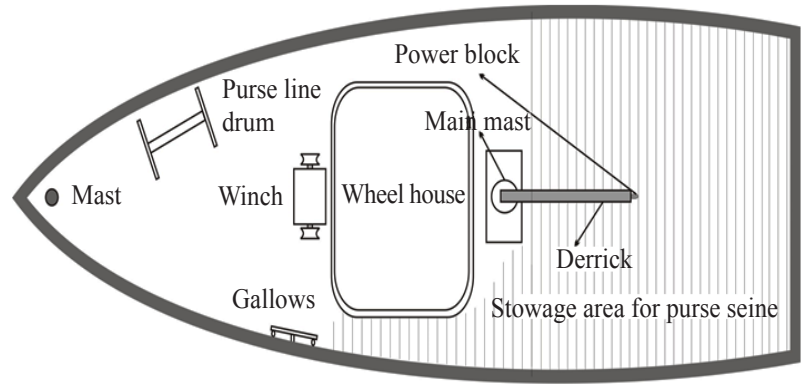

Fig. 1. General deck layout of a typical mechanised purse seiner in India

Table 1. Details of purse seiners in the country

\begin{tabular}{lllllll}
\hline State & $\begin{array}{l}\text { Purse seiners } \\
\text { (Nos.) }\end{array}$ & $\mathrm{L}_{\mathrm{OA}}(\mathrm{m})$ & $\begin{array}{l}\text { Engine horsepower } \\
(\mathrm{hp})\end{array}$ & $\begin{array}{l}\text { Length of } \\
\text { purse seine }(\mathrm{m})\end{array}$ & $\begin{array}{l}\text { Depth of } \\
\text { purse seine }(\mathrm{m})\end{array}$ & $\begin{array}{l}\text { Mesh size } \\
(\mathrm{mm})\end{array}$ \\
\hline Maharashtra & 435 & $14-18$ & $110-240$ & $700-1500$ & $70-100$ & $24-46$ \\
Goa & 296 & $15-22$ & $140-350$ & $450-1500$ & $60-100$ & $18-46$ \\
Karnataka & 422 & $11-21$ & $120-350$ & $800-1200$ & $80-100$ & $24-46$ \\
Kerala & 60 & $18-24$ & $120-510$ & $600-1200$ & $70-100$ & $36-45$ \\
Total & 1213 & $11-24$ & $110-510$ & $450-1500$ & $60-100$ & $18-46$
\end{tabular}

Source: Edwin and Hridayanathan (1996); CMFRI (2010) 


\section{Fishing gear}

A purse seine is made of a long wall of netting framed with float line in the head rope and lead line in the foot rope, having purse rings hanging from the lower edge of the gear, through which runs a purse line which facilitates the pursing of the net. The overall length of the purse seine net is expressed as the length of the float line. As a thumb rule, the depth of the net is about $10 \%$ of the length of the float line. It varies from one-third to one-fourth for deep swimming and quick diving fish shoals. The lead line is usually longer than the float line by 5 to $12 \%$. The bunt is usually as long and deep as the length of the boat.

Fishing gear materials used for the purse seine net have not changed much, over the years. Usually, thicker twine size and smaller mesh sizes are used in the bunt region as compared to the mesh and twine sizes used in the main body of the purse seine net. The most important requirements of a purse seine netting material is high breaking strength, high sinking speed and water shedding capacity. Polyamide (PA), polyester (PES) and polyvinyl alcohol (PVA) netting yarns meet these requirements. PA popularly known as nylon has been the most preferred material for purse seine in India. Twisted knotless nylon netting and raschel knotless netting are lighter and were widely used for constructing purse seines. However, nowadays, only knotted PA netting are used by fishermen, due to ease of repair when damaged. Polyethylene (PE) of thicker dia and larger mesh size is used for the selvedge. PA or PES of 11 to $12 \mathrm{~mm}$ dia was used earlier for the head rope and foot rope. Presently polypropylene (PP) ropes of 12 and $10 \mathrm{~mm}$ dia in double are used for the head rope and foot rope respectively; while $24 \mathrm{~mm}$ dia PP ropes are used for the purse line. Mesh sizes of the main body range from 16 to $18 \mathrm{~mm}$ whereas $12 \mathrm{~mm}$ is used for the bunt region. Large mesh sizes were used for the selvedges, which ranged from 20 to $70 \mathrm{~mm}$ for the upper selvedges, lower selvedges and guarding meshes (Hameed and Mukundan, 1991). One important factor is that the mesh size of the purse seine must be appropriate and small enough to prevent gilling of target fish, as clearing of the gilled fish is difficult. The major changes in the net and its accessories over the years are given in Table 2.

A few standard purse seine designs developed in India by the erstwhile Indo-Norwegian Project have been described by Verghese (1976). The design and operation of a $320 \mathrm{~m}$

Table 2. Major change in the purse seine and its accessories over the years

\begin{tabular}{|c|c|c|c|c|c|c|}
\hline Details & 1970 & 1974 & 1974 & 1980 & 2011 & 2010 \\
\hline Length of purse seine & $320 \mathrm{~m}$ & $292 \mathrm{~m}$ & $366 \mathrm{~m}$ & $350 \mathrm{~m}$ & $723 \mathrm{~m}$ & $1000 \mathrm{~m}$ \\
\hline Depth of purse seine & $20-28 \mathrm{~m}$ & $27 \mathrm{~m}$ & $46 \mathrm{~m}$ & $39 \mathrm{~m}$ & - & $72 \mathrm{~m}$ \\
\hline $\begin{array}{l}\text { Head rope material and } \\
\text { specifications }\end{array}$ & PES, $11 \mathrm{~mm}$ dia & PES, $11 \mathrm{~mm}$ dia & PES, $22 \mathrm{~mm}$ dia & PES, $10 \mathrm{~mm}$ dia & PP, $12 \mathrm{~mm}$ dia & $\mathrm{PP}, 12 \mathrm{~mm}$ dia \\
\hline $\begin{array}{l}\text { Length of foot rope, material } \\
\text { and specifications }\end{array}$ & $\begin{array}{l}330 \mathrm{~m}, \mathrm{PES}, \\
12 \mathrm{~mm} \text { dia }\end{array}$ & $\begin{array}{l}309 \mathrm{~m}, \mathrm{PES}, \\
12 \mathrm{~mm} \text { dia }\end{array}$ & $\begin{array}{l}383 \mathrm{~m}, \mathrm{PES}, \\
25 \mathrm{~mm} \text { dia }\end{array}$ & $\begin{array}{l}370 \mathrm{~m}, \text { PES, } \\
10 \mathrm{~mm} \mathrm{dia}\end{array}$ & $\begin{array}{l}747 \mathrm{~m}, \mathrm{PP}, \\
10 \mathrm{~mm} \text { dia }\end{array}$ & $\begin{array}{l}1188 \mathrm{~m}, \mathrm{PP}, 12 \mathrm{~mm} \\
\operatorname{dia} \times 2\end{array}$ \\
\hline $\begin{array}{l}\text { Main netting specifications: } \\
\text { material, twine size, mesh } \\
\text { size }\end{array}$ & PA knotless & PA $210 \mathrm{~d} \times 3 \times 3$ & PA $210 \mathrm{~d} \times 3 \times 3$ & $\begin{array}{l}\text { PA } 210 \mathrm{~d} \times 2 \times 3,15 \mathrm{~mm} \\
\text { mesh size knotless }\end{array}$ & $\begin{array}{l}\text { PA } 210 \mathrm{~d} \times 6 \times 3, \\
30 \mathrm{~mm} \text { and } 15 \mathrm{~mm} \\
\text { mesh size }\end{array}$ & $\begin{array}{l}\text { PA } 210 \mathrm{~d} \times 4 \times 345 \\
\text { mm and } 15 \mathrm{~mm} \\
\text { mesh size }\end{array}$ \\
\hline $\begin{array}{l}\text { Bunt netting material } \\
\text { specification: material, twine } \\
\text { size, mesh size }\end{array}$ & - & PA $210 \mathrm{~d}$ x 4 x 3 & PA $210 \mathrm{~d} \times 4 \times 3$ & $\begin{array}{l}\text { PA } 210 \mathrm{dx} 3 \times 3 \\
15 \mathrm{~mm} 15 \mathrm{~mm} \text { mesh size } \\
\text { knotless }\end{array}$ & - & PA $210 \mathrm{dx} 6 \mathrm{x} 3$ \\
\hline $\begin{array}{l}\text { Selvedge material } \\
\text { specifications }\end{array}$ & - & $\begin{array}{l}\text { PA } 210 \times 3 \times \\
3,210 \times 4 \times 3 \\
\text { and } 210 \times 6 \times 3, \\
11 \text { meshes deep }\end{array}$ & $\begin{array}{l}\text { PA } 210 \times 4 \times 3, \\
210 \times 5 \times 3,210 \times \\
6 \times 31.25 \text { m on top }\end{array}$ & $\begin{array}{l}\text { Top and sides: PA } 210 \text { x } \\
(3 / 4 / 6 /) \times 3 \text {, each } \\
25 \text { meshes deep, } 15 \mathrm{~mm} \\
\text { knotted; Bottom: PA } 210 \\
\text { x }(14 / 16 / 18 /) \text { x } \\
3,70 \mathrm{~mm} \text { mesh size, } \\
\text { knotted, } 5 \text { meshes deep }\end{array}$ & - & $\begin{array}{l}\text { PP } 1.5 \mathrm{~mm} \text { dia } \\
45 \mathrm{~mm} \text { mesh size in } \\
\text { head rope, } 7 \text { meshes } \\
\text { deep and PP } 2.5 \mathrm{~mm} \\
\text { dia in foot rope, } \\
11 \text { meshes deep }\end{array}$ \\
\hline Sinker material specifications & - & $\begin{array}{l}\mathrm{Pb} 300 \mathrm{~g} \text { each, } \\
680 \text { nos. }\end{array}$ & $\begin{array}{l}\mathrm{Pb} 250 \mathrm{~g} \text { each, } \\
680 \text { nos. }\end{array}$ & $\mathrm{Pb} 250 \mathrm{~g}$ each, 640 nos. & $\begin{array}{l}\mathrm{Pb} 220 \mathrm{~g} \text { each, } \\
4180 \text { nos. }\end{array}$ & $\begin{array}{l}\mathrm{Pb} 200 \mathrm{~g} \text { each, } \\
5000 \text { nos. }\end{array}$ \\
\hline $\begin{array}{l}\text { Float material and } \\
\text { specifications }\end{array}$ & - & $\begin{array}{l}\text { PVC, } 10 \times 5 \mathrm{~cm}, \\
1920 \text { nos. }\end{array}$ & $\begin{array}{l}\text { PVC, } 10 \times 5 \mathrm{~cm}, \\
1920 \text { nos. }\end{array}$ & $\begin{array}{l}\text { PVC, } 250 \text { mm, egg } \\
\text { shaped } 845 \text { nos., } 100 \times 50 \\
\text { mm } 1920 \text { nos. }\end{array}$ & $\begin{array}{l}\text { PVC, } 135 \times 85 \mathrm{~mm} \\
866 \text { nos., } 160 \times 120 \\
\text { mm, EVA } 85 \times 85 \\
\text { mm } 5357 \text { nos. }\end{array}$ & $\begin{array}{l}\text { PVC oval, } 150 \mathrm{~mm} \\
\text { dia, } 6000 \text { nos. }\end{array}$ \\
\hline $\begin{array}{l}\text { Purse ring material and } \\
\text { specifications }\end{array}$ & - & $\begin{array}{l}\text { Brass } 1.5 \mathrm{~kg} \text { each, } \\
30 \text { nos. }\end{array}$ & $\begin{array}{l}\text { Brass } 2 \mathrm{~kg} \text { each, } \\
28 \text { nos. }\end{array}$ & $\begin{array}{l}\text { GI rod } 20 \mathrm{~mm} \text { dia. } \\
1.25 \mathrm{~kg} \text { each, } 31 \mathrm{nos} .\end{array}$ & $\begin{array}{l}\text { Brass } 120 \mathrm{~mm} \text { dia., } \\
2.5 \mathrm{~kg} \text { each, } 53 \text { nos. }\end{array}$ & $\begin{array}{l}\text { Brass } 1.3 \mathrm{~kg} \text { each, } \\
85 \text { nos. }\end{array}$ \\
\hline Total weight of gear & - & $1400 \mathrm{~kg}$ & $3050 \mathrm{~kg}$ & $3050 \mathrm{~kg}$ & - & $3500 \mathrm{~kg}$ \\
\hline $\begin{array}{l}\text { Approximate cost of purse } \\
\text { seine net }\end{array}$ & - & ₹ 0.11 million & ₹. 0.15 million & ₹ 0.114 million & - & ₹ 1.7 million \\
\hline References & Menon (1970) & Verghese (1976) & Verghese (1976) & Mukundan et al. (1980) & IS: 5508 (1975) & $\begin{array}{l}\text { Meenakumari et al. } \\
(2010)\end{array}$ \\
\hline
\end{tabular}


long purse seine with maximum depth of $28 \mathrm{~m}$ suitable for operation on $10.9 \mathrm{~m} \mathrm{~L}_{\mathrm{OA}}$ vessel has been described by Menon (1970). Design details of a purse seine of size 292 × $28 \mathrm{~m}$ suitable for fishing vessels of size $10.8 \mathrm{~m} \mathrm{~L}_{\mathrm{OA}}$ are given in
Fig. 2 and design details of a $300 \mathrm{~m}$ purse seine net and a $350 \mathrm{~m}$ purse seine net are given in Figs. 3 and 4 respectively. A few standard purse seine designs as per Indian Standards are given in Figs. 5 to 7 (IS:5508, 1975).

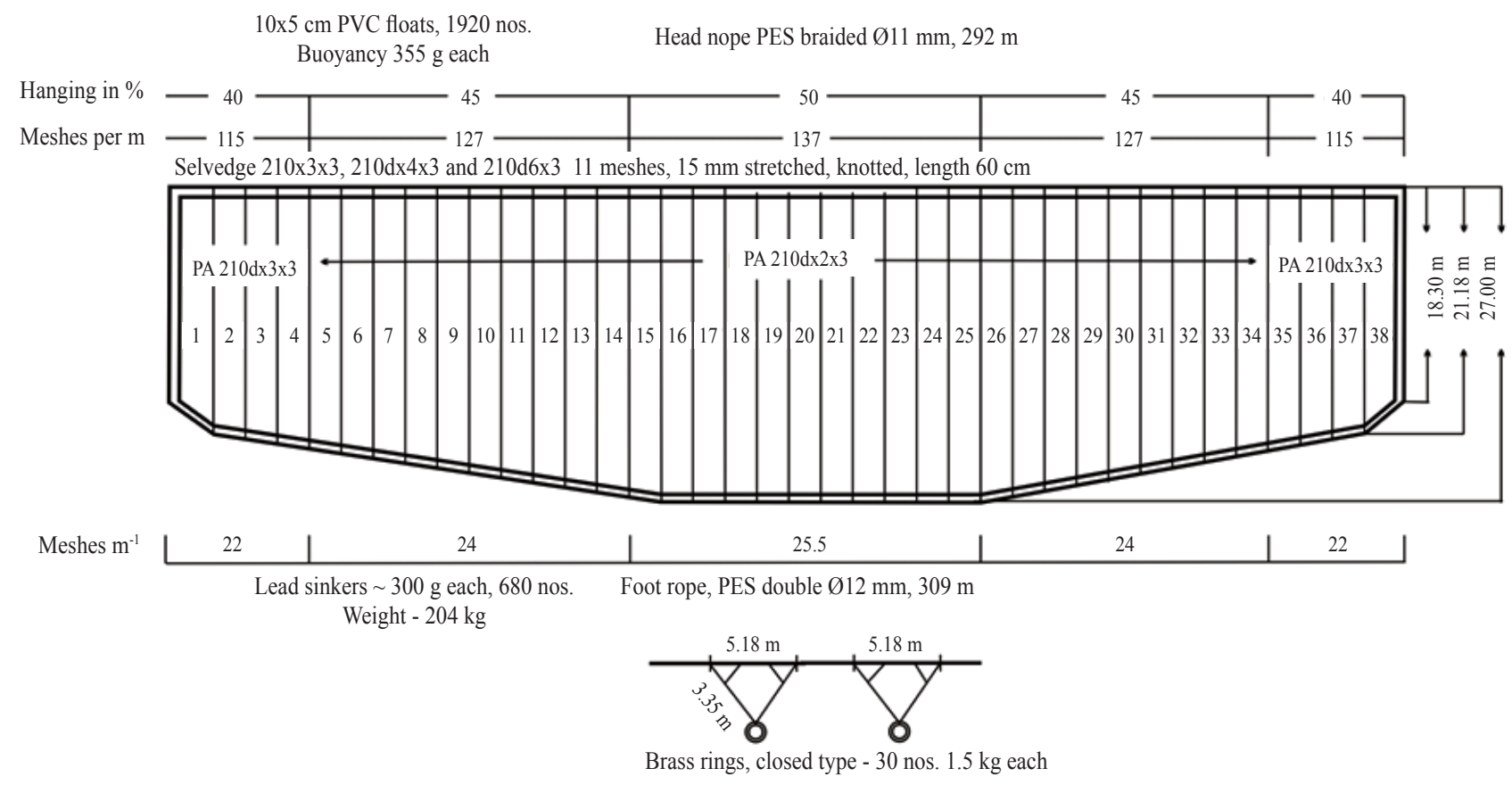

Fig. 2. Design of $292 \mathrm{~m}$ purse seine for $10.8 \mathrm{~m}$ vessel(Verghese, 1976)

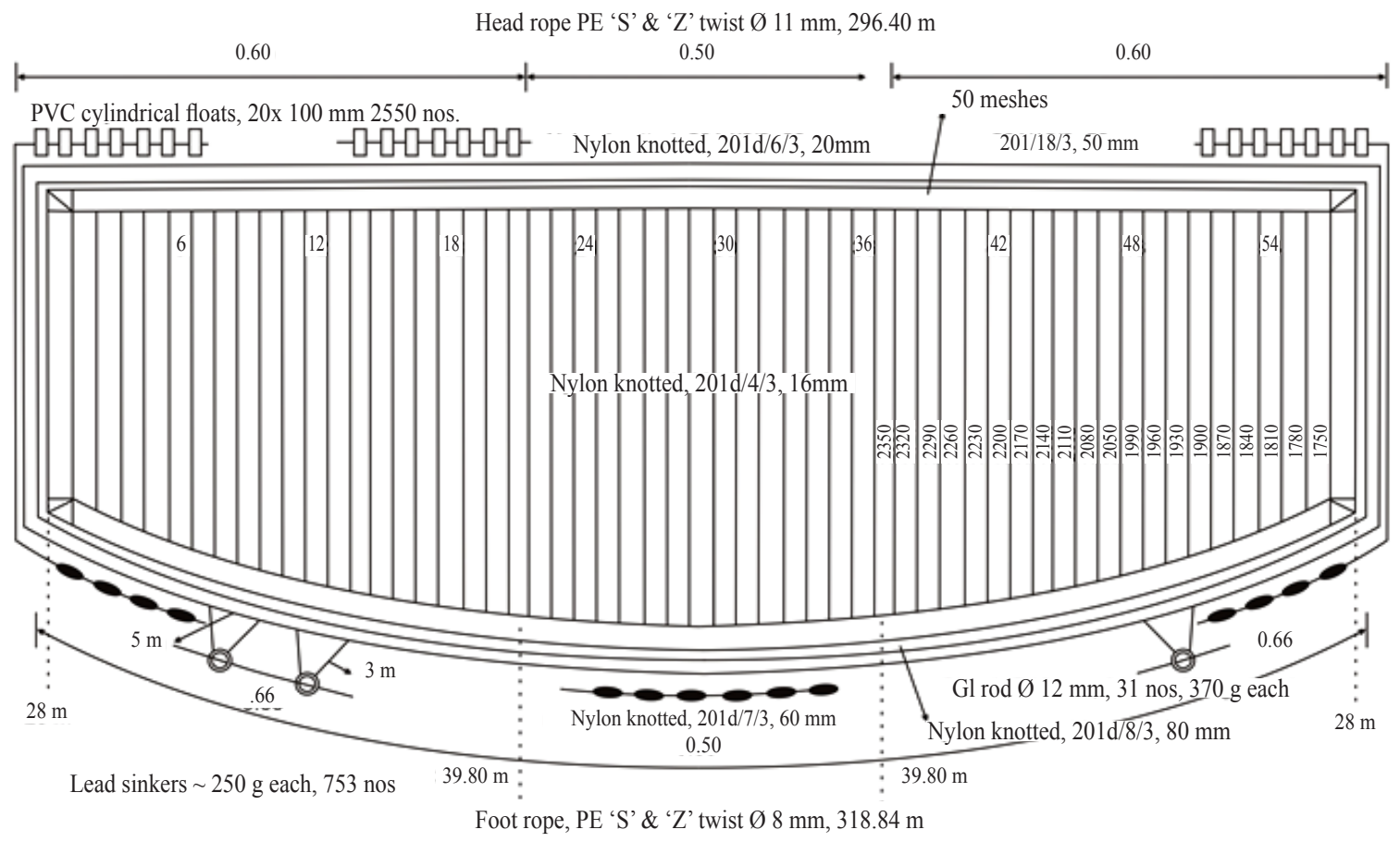

Bunt, PA 201/2/3 mesh size, 12 mm knotted; Main body PA 201/4/3 mesh size, 16 mm knotted; Top and sides PA 201/6/3 mesh size, 20 mm knotted 50 meshes depth; Bottom PA 201/7/3 mesh size, 60 mm knotted 20 meshes depth

Fig. 3. Design of $300 \mathrm{~m}$ purse seine for $13.27 \mathrm{~m}$ vessel (Mukundan et al., 1980) 


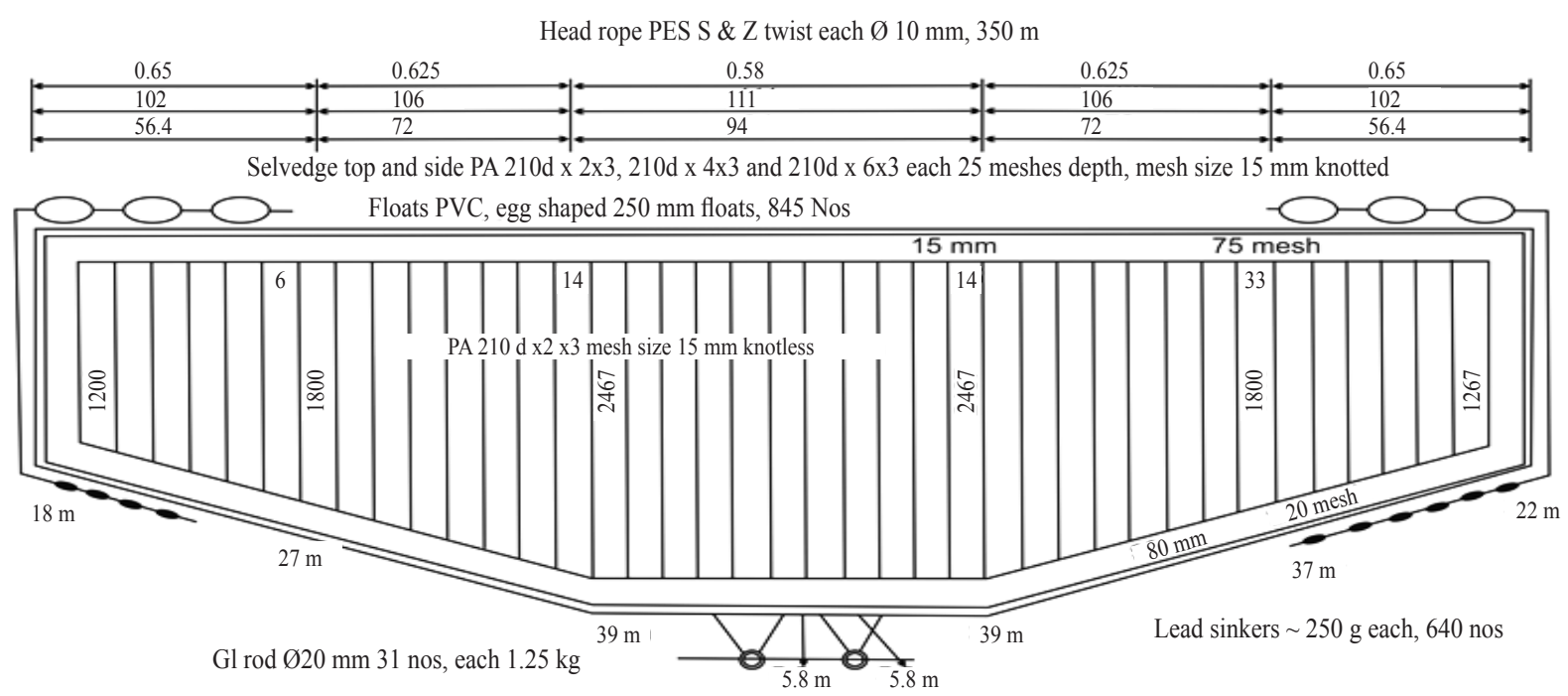

Selvedge bottom PA $210 \mathrm{~d} \times 14 \times 3,210 \mathrm{~d} \times 16 \times 3$ and $210 \mathrm{~d} \times 18 \times 3$ each 5 meshes depth, mesh size 70 mm knotted Foot rope PES S \& Z twist each Ø $10 \mathrm{~mm}, 370 \mathrm{~m}$

Fig. 4. Design of $350 \mathrm{~m}$ purse seine for $13.10 \mathrm{~m}$ vessel (Mukundan et al., 1980)

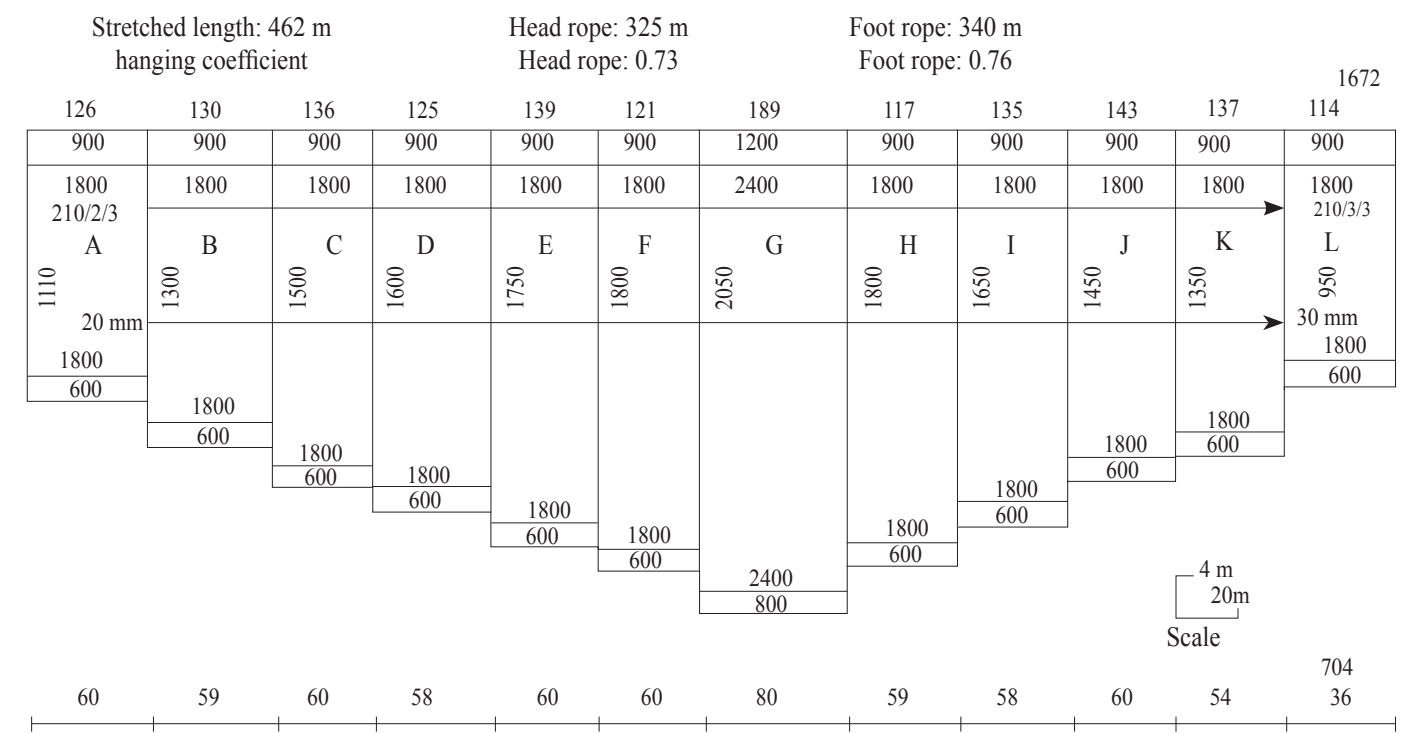

Selvedge : Top: 2.5 meshes deep: $40 \mathrm{~mm} .210 / 6 / 3$

Bottom : 5 meshes deep: $60 \mathrm{~mm}$. 210/6/3

Fig. 5. Design of $325 \mathrm{~m}$ purse seine (IS:5508,1975)

A slightly larger sized net $366 \mathrm{~m}$ in length and $36 \mathrm{~m}$ in depth having $15 \mathrm{~mm}$ mesh size weighing about $3 \mathrm{t}$ has been described by Verghese (1973) and this was operated by mechanised boats of size $17.5 \mathrm{~m} \mathrm{~L}_{\mathrm{OA}}$ in off shore areas (Fig. 8). Mukundan et al. (1980) made a purse seine design suitable for $13.2 \mathrm{~m} \mathrm{~L}_{\mathrm{OA}}$ vessel. Mukundan and Hakim (1980) described a $410 \mathrm{~m}$ net suitable for vessels up to $15 \mathrm{~m} \mathrm{~L}_{\mathrm{OA}}$ fishing vessels (Fig. 9). Design details of a $502 \mathrm{~m}$ purse seine for operation from $27.31 \mathrm{~m} \mathrm{~L}_{\mathrm{OA}}$ purse seiner are given in Fig. 10. Fig. 11 depicts design details of a $723 \mathrm{~m}$ purse seine net with pockets operated in Ratnagiri (Jadhav et al., 2011). Pravin and Meenakumari (2011b) described the design details of a $1000 \mathrm{~m}$ purse seine net (Fig. 12). In the initial years, purse seiners at Kochi were operating with mesh sizes ranging from 10 to $20 \mathrm{~mm}$. Purse seine nets of $1200 \mathrm{~m}$ length and 72-125 m depth weighing approximately 3 to $4 \mathrm{t}$ are now being used. Presently, the head rope length of purse seines range from 450 to $1500 \mathrm{~m}$ with mesh size ranging from 18 to $46 \mathrm{~mm}$ in the main body (Edwin et al., 2014). 


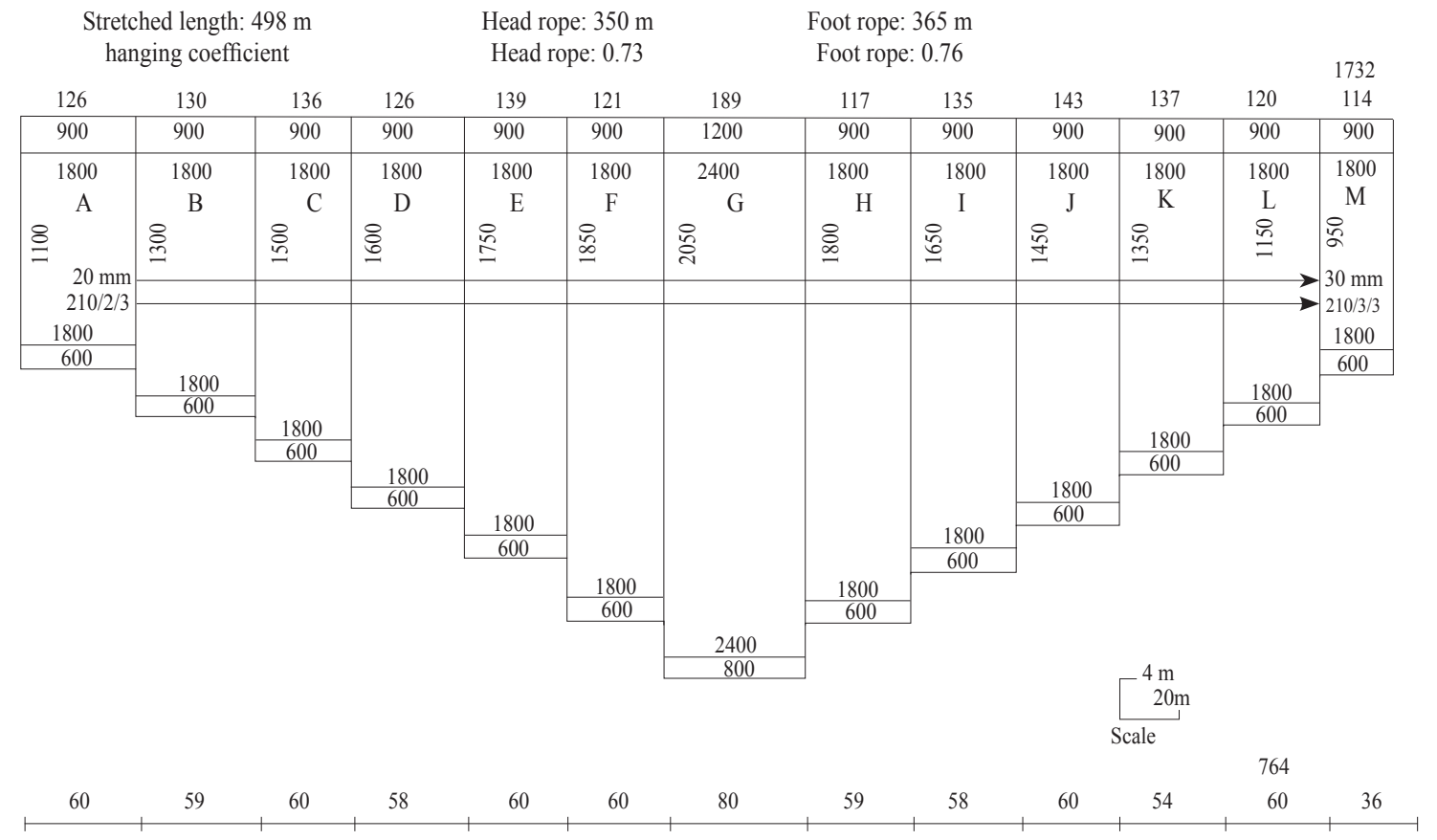

Selvedge : Top: 2.5 meshes deep: $40 \mathrm{~mm} .210 / 6 / 3$

Bottom : 5 meshes deep: 40 mm. 210/6/3

Fig. 6. Design of $350 \mathrm{~m}$ purse seine (IS:5508, 1975)

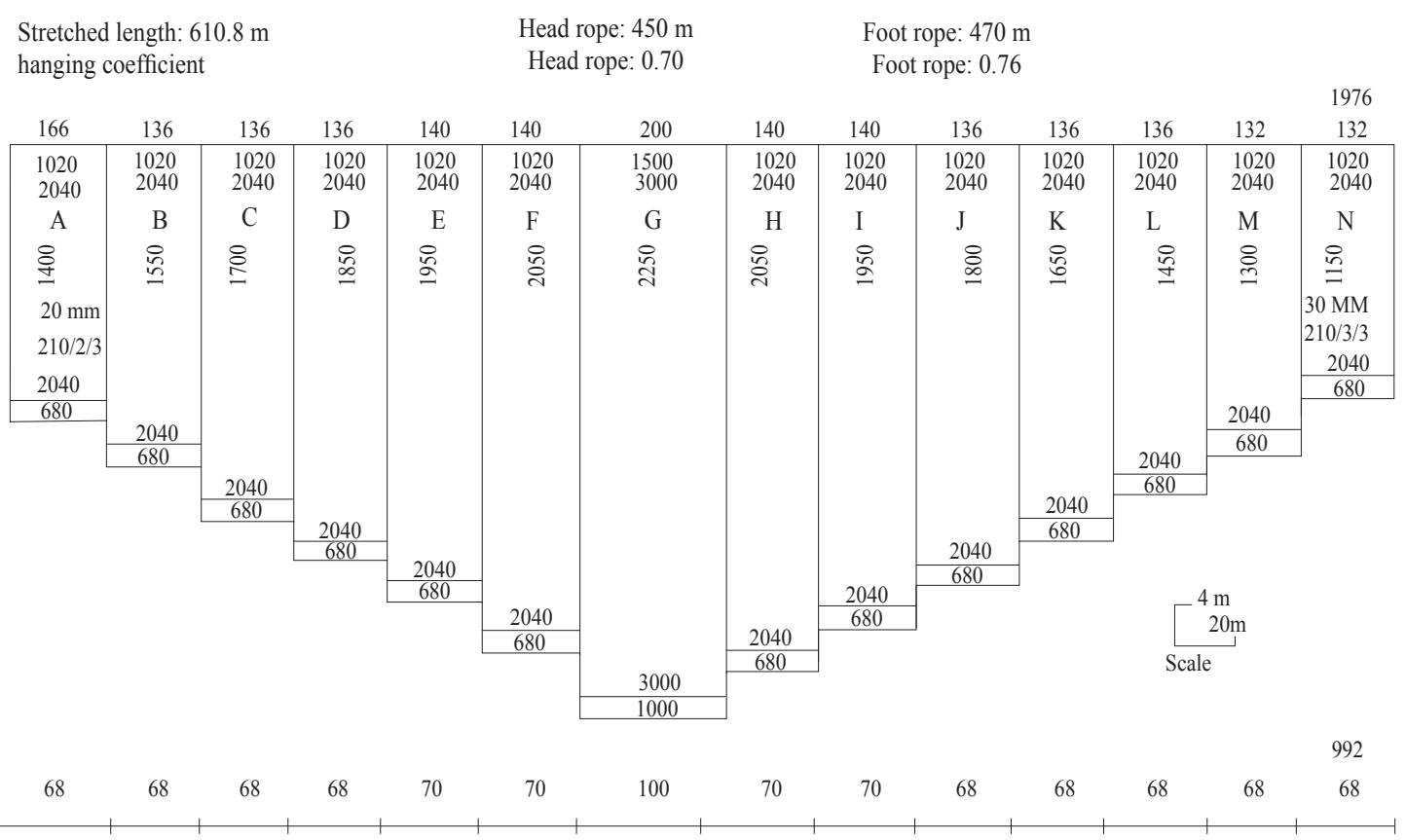

Selvedge : Top: 2.5 meshes deep: $40 \mathrm{~mm}$. 210/6/3

Bottom : 5 meshes deep: $60 \mathrm{~mm} .210 / 6 / 3$

Fig. 7. Design of $450 \mathrm{~m}$ purse seine (IS:5508, 1975) 


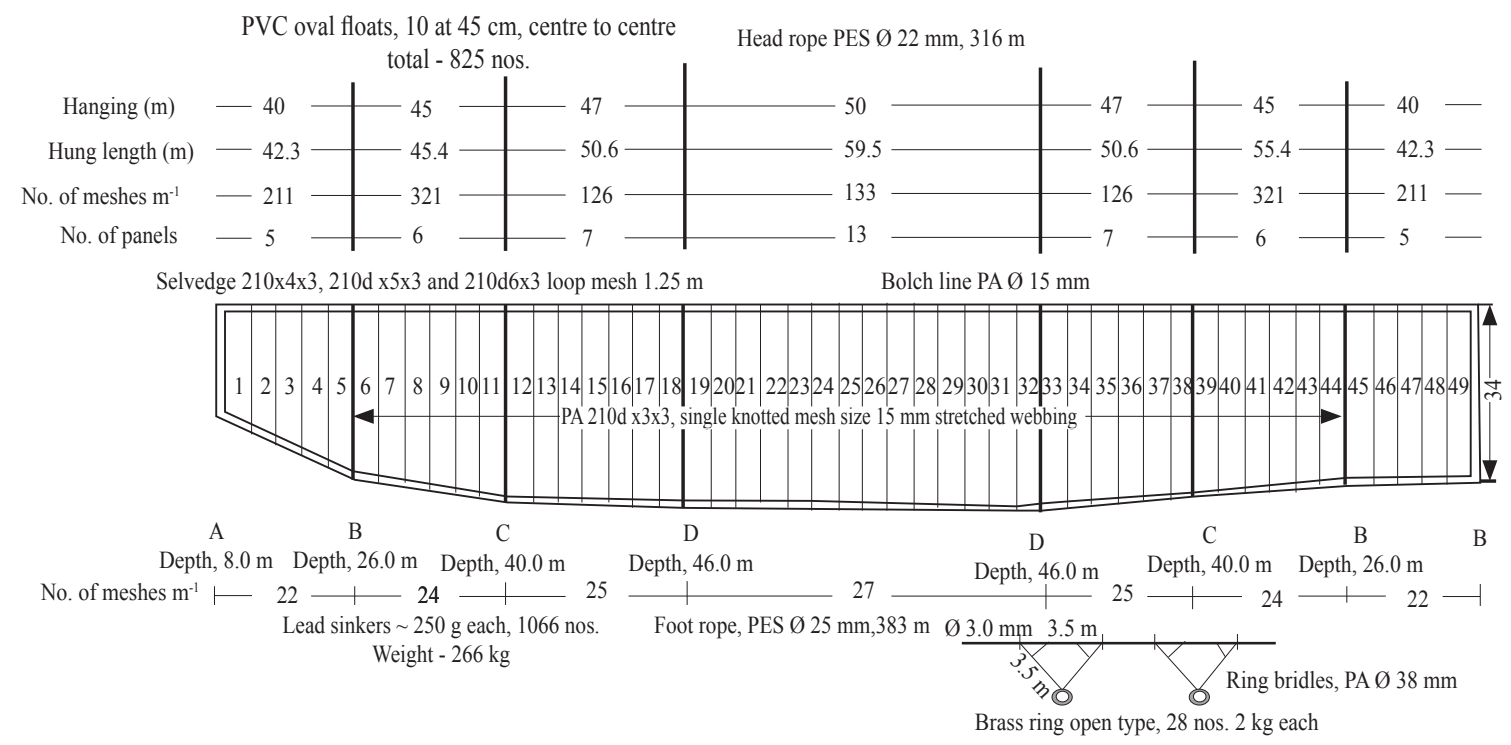

Fig. 8. Design of $366 \mathrm{~m}$ purse seine for $17.50 \mathrm{~m}$ vessel (Verghese, 1976)

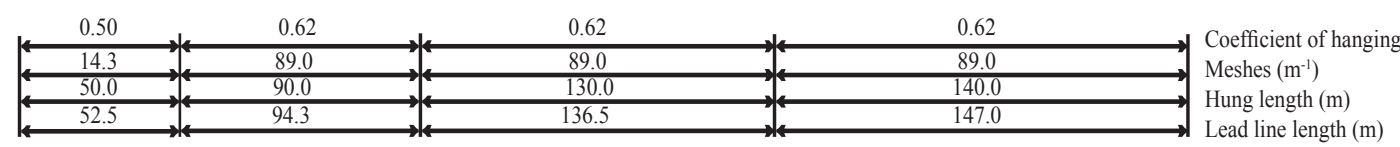

Float PVC oval 150x100 cm 100 nos. Cylindrical 125x100, 2165 nos.

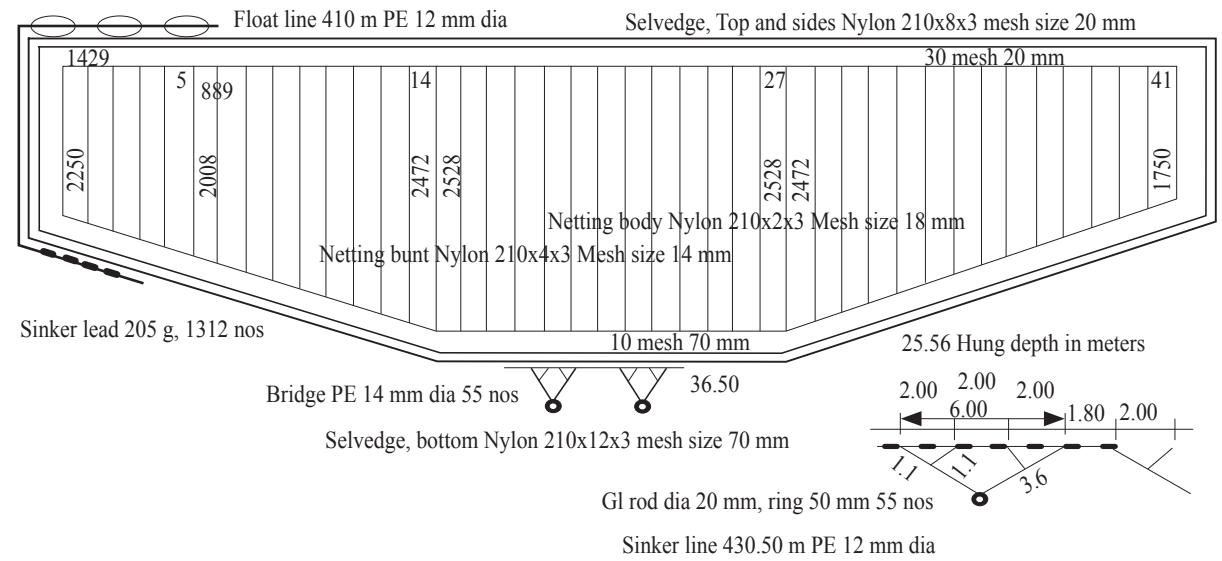

Fig. 9. Design of $410 \mathrm{~m}$ purse seine for $13.10 \mathrm{~m}$ fishing vessel (Mukundan and Hakim, 1980)

Purse seiners operating nets with small mesh sizes ranging from $12-15 \mathrm{~mm}$ for both small and large pelagic species, tend to retain juveniles of important pelagic resources like oilsardine, mackerel, horse mackerel and scads (Rao et al., 1982). Adoption of appropriate mesh size is therefore required to minimise juvenile fishing mortality, during purse seine operations. Meenakumari et al. (2010) introduced large mesh size of $45 \mathrm{~mm}$ in the body of the purse seine for targeting pelagic resources in deeper and farther waters. This eased the fishing pressure on coastal resources as these nets could be operated in deeper waters to target other valuable resources like tunas and other large pelagics which also helped to avoid competition with the ring seiners. The large meshed net reduced the landings of juveniles of mackerel and helped to completely avoid anchovies and sardines, while catching good quality large pelagic fishes which fetch better prices.

\section{Fishing operations}

Purse seine is the most important gear for catching pelagic shoaling fish and includes all the elements of searching, hunting and capture. The success of purse seine operation depends on the availability of shoals, manoeuvrability of the vessel and quick encirclement of the shoal. Purse seining in the country is mostly confined to the coastal waters.

Description of the purse seines and their operation has been reported by many authors (Menon, 1970; Verghese, 


\begin{tabular}{|c|c|c|c|c|c|c|c|c|}
\hline 0.59 & 0.61 & 0.59 & 0.57 & 0.56 & 0.57 & 0.65 & 0.75 & \multirow{4}{*}{$\begin{array}{l}\text { Coefficient of hanging } \\
\text { Meshes }\left(\mathrm{m}^{-1}\right) \\
\text { Hung length }(\mathrm{m}) \\
\text { Lead line length }(\mathrm{m})\end{array}$} \\
\hline 71 & 68 & 71 & 73 & 74 & 73 & 64 & 56 & \\
\hline 68 & 56.20 & 85 & 54.70 & 134.40 & 54.70 & $\overrightarrow{31.20}$ & $\overleftrightarrow{18.0}$ & \\
\hline 70.44 & 61.64 & 93.60 & 60.50 & 148.80 & 60.50 & 34.60 & $\overrightarrow{19.92}$ & \\
\hline
\end{tabular}

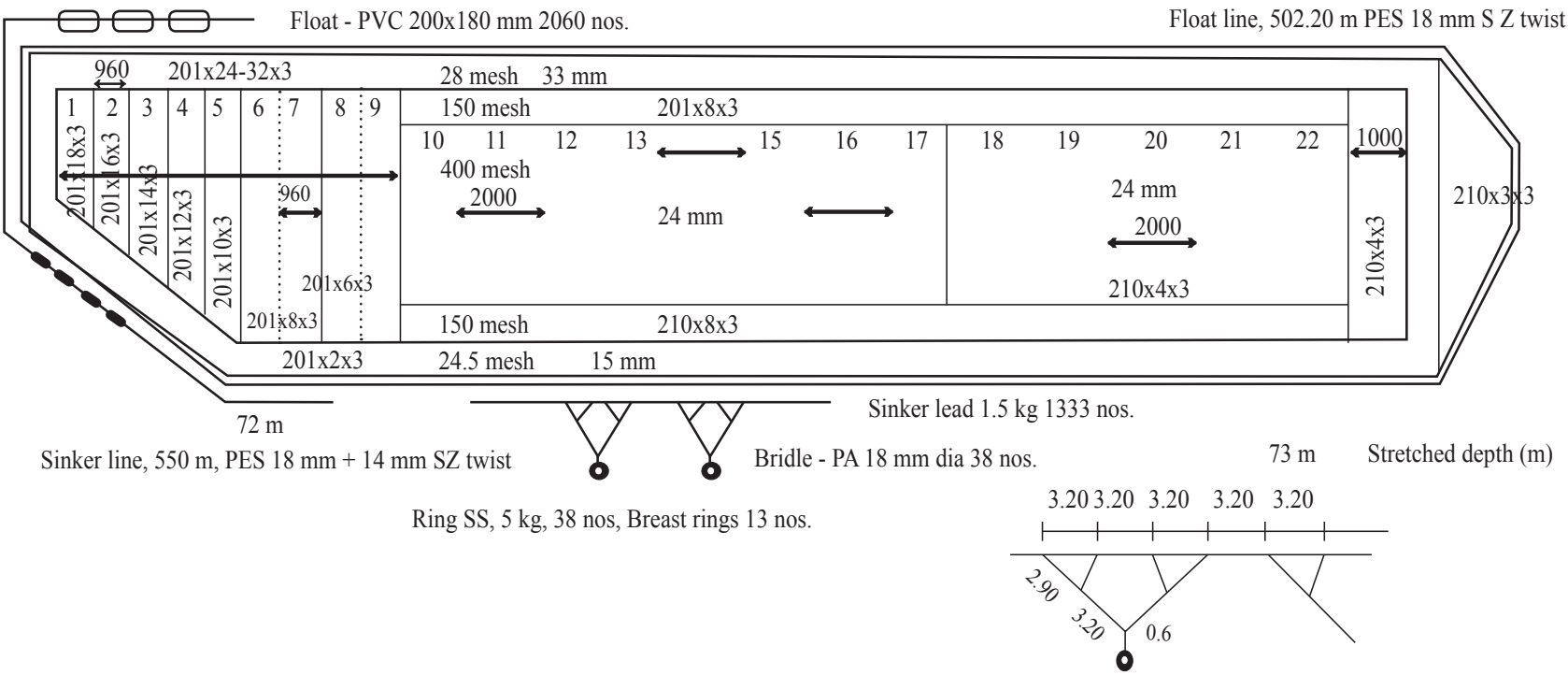

Fig. 10. Design of $502 \mathrm{~m}$ purse seine for $27.31 \mathrm{~m}$ fishing vessel (Mukundan and Hakim, 1980)

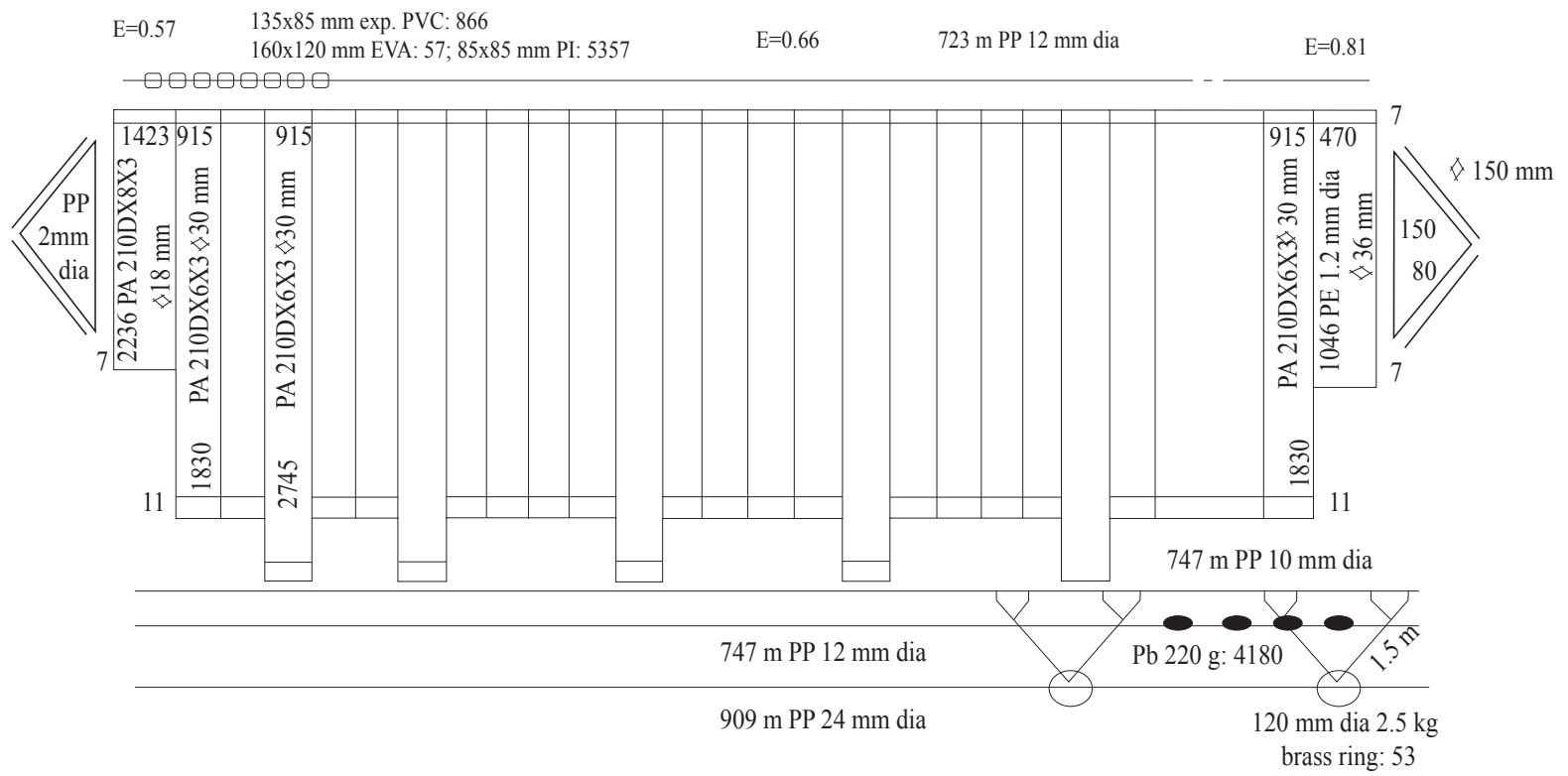

Fig. 11. Design of small meshed purse seine net with pocket operated from Ratnagiri (Jadhav et al., 2011)

1973 and 1976; Hameed and Asok, 1987; Ben Yami, 1994 a,b; Hameed and Boopendranath, 2000; Meenakumari et al., 2010; Pravin and Meenakumari, 2011a). Single-boat purse seining for mackerel and sardines with the aid of a skiff is practised off Kerala. Earlier, both starboard and port side operations were carried out, but presently only port side operations are carried out. Occasionally, purse seine operations are also carried out during night. It usually commences during the second quarter in the darker lunar phase in Karnataka (Kempuraju et al., 1993). Purse seining during night using lights in Kerala has been reported by Pravin (2012).

Single-boat purse seining is practiced in the country with the assistance of a skiff. After encircling the fish shoal, the bottom of the net is closed by hauling the purse line with help of purse line winch. Once the bottom of the net is closed, 


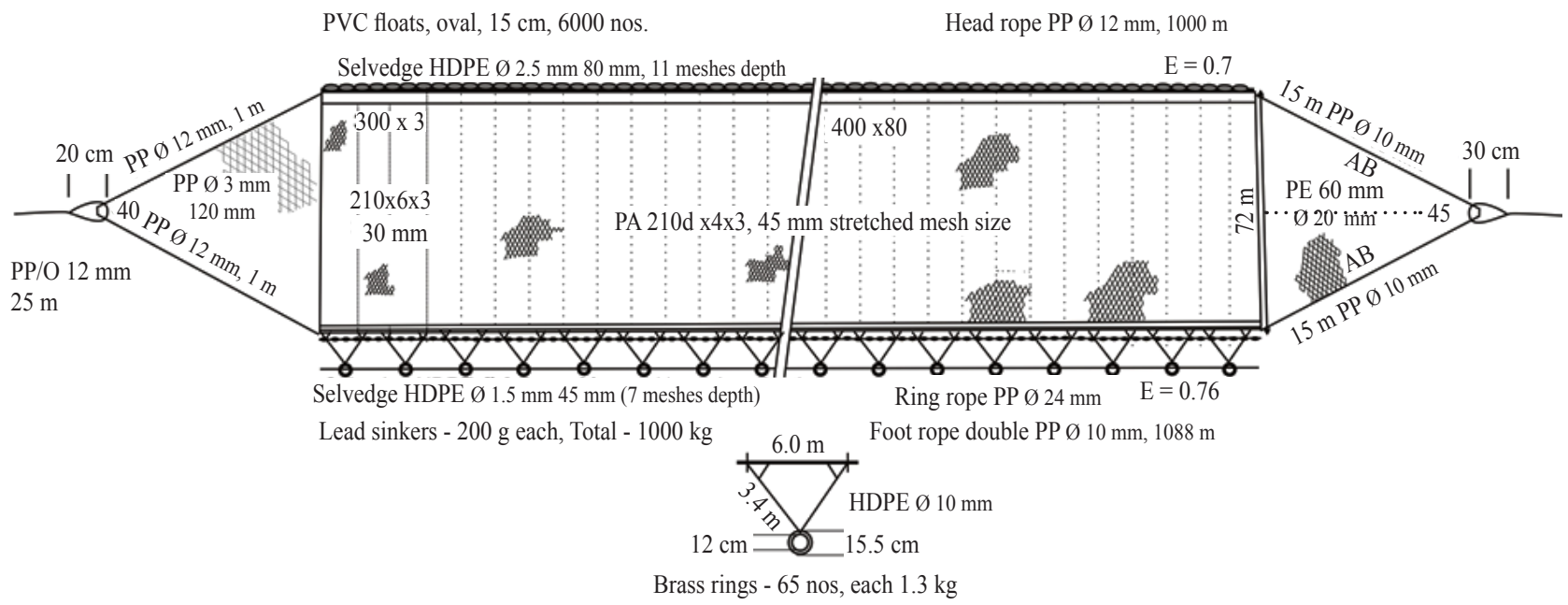

Fig. 12. Design of $1000 \mathrm{~m}$ purse seine (Meenakumari et al., 2010)

the net is hauled up until the catch is accumulated in the bunt region. Catch is taken onboard by brailing using large scoop nets. As the purse seine net is very large and heavy, 20 to 30 crew members are required for the fishing operations. Shooting of the purse seine net is done from the stern side of the vessel which has a smooth gunwale to avoid any fouling of the net. Hauling of the net is done from the port side of the vessel. The fish shoals in the inshore areas are easily detected by visual observation from an elevated point in the boat. The fishermen are also able to operate the nets during night with the help of SONAR. After the location of the shoal, the end of the net where bridle and buoys are provided, along with one end of the purse seine is given to the skiff and the vessel moves forward at maximum speed releasing the net and encircling the shoal at the quickest possible time. During this process, the purse line, which is coiled on the winch drum, is also released. After the fish shoal is completely encircled, the purse line end which was with the skiff, is taken back to the main vessel. The two ends of the pursed line are then pulled fast with the help of the purse line winch. After pursing the bottom, the gallows is reversed on the deck, purse rings are arranged, the engine stopped and net is hauled up manually by pulling the lead line, float line and netting, at the same time. As soon as the ropes and major portion of the netting are hauled inside, the catch concentrated in the bunt are brailed in using a scoop net. The fish is stored on the deck in case of single day fishing and stored in the fish hold with ice, for multiday fishing. The hauling operation is labour intensive and requires 2 to $3 \mathrm{~h}$. Now, with the installation of power block on the boat, the net is hauled up easily and it takes only about 45 min to haul up the net (Pravin and Meenakumari, 2011). Depth of operation has now increased as compared to the past due to increase in size of craft and horse power of engine. Usually single day operations are practiced in Kerala and Karnataka, while multiday operations are being carried out from Goa (Edwin et al., 2014).

\section{Purse seine catch}

Purse seining is mainly used for harvesting shoaling fishes such as mackerel, sardines, whitebaits, carangids, tuna, pomfrets, barracudas, wolf herring and other species. Mechanised purse seining contributes about $6 \%$ to the total marine landings in India (CMFRI, 2014). Introduction of purse seines in India can be considered as one of the most significant development in the marine sector for commercial exploitation of pelagic resources (Rao et al., 1982). Purse seining for whitebaits is carried out at 15 to $20 \mathrm{~m}$ within a distance of about 5-8 $\mathrm{km}$ from the shore during day time in October to December, the peak season of abundance. Whitebait fishery is mainly sustained by three species viz., Stolephorus devisi, S. bataviensis and S. buccaneeri. The purse seine fishery for oilsardine shows wide fluctuations which is an inherent characteristic of fishery of the species (Balan, 1973, 1984; Jacob et al., 1982; Balan and Nizar, 1988). In addition to sardine, mackerel and anchovies, other fishes are also caught in purse seine nets. Pomfrets, mainly Parastromateus niger are also exploited by purse seiners during a short period from September to November (Kulkarini et al., 1991). Kemparaju et al. (1992) and Chaniyappa (2009) reported bumper landings of catfish by purse seiners at Malpe Fisheries Harbour, Karnataka. Landings of Arius dussumieri was reported by Katkar et al. (2004) at Sassoon Dock, Mumbai. Landings of Alepes djedaba and Megalaspis cordyla were reported by Jadhav et al. (2004) and landings of Rachycentron canadum by Jadhav and Chavan (2004) in Mumbai. Landings of shrimps (Fenneropenaeus indicus and Metapenaeus dobsoni) has been reported by many (Nair et al., 1982; Nair and Narayanakutty, 1985; Kulkarni et al., 1987; Sukumaran, 1993; Udaya, 2004). Sharks were also landed in a purse seine at Malpe, Karnataka (Mohamad et al., 1993). Landings of tongue sole by purse seiners at Mangalore and Malpe, Karnataka coast have also been observed 
(Zacharia et al., 1991). Other commercially important fishes such as tunas, seer fishes, pomfrets and carangids are also often caught by the net. The fishing season for sardine and mackerel commences by the middle of October and lasts up to the end of December. However, with the improved large mesh purse seine net, the fishermen could operate in deeper waters targeting tunas and other large pelagic fishes.

Catch composition of the landings by large mesh purse seines operated off Kochi during 2008-09 in the depth range of 50-220 m comprised of large sized mackerels (62\%), followed by tunas $(16 \%)$, carangids (14\%), seerfishes $(3 \%)$, pomfrets $(2 \%)$ and miscellaneous fishes (3\%), (Mukundan et al.,1980). The absence of sardine was conspicuous due to the use of large mesh. Landings of tuna and other quality fishes were mainly from depths beyond $50 \mathrm{~m}$. Landing of quality fishes by the large mesh purse seines gave an impetus to the purse seine fishermen as it fetched better value for their catch, compared to the conventional (small mesh) purse seine landings (Pravin and Meenakumari, 2011a; Meenakumari et al., 2010; Pravin and Meenakumari, 2013a and 2013b).

\section{Bycatch and environmental issues}

The main negative impact is the incidental capture of dolphins, sea turtles and sharks in certain fishing areas (eastern and western Pacific, eastern Atlantic and western Indian Oceans) in the tropical tuna purse seine fisheries of the world (Hall and Roman, 2013). There are not many reports of incidental bycatch landings like dolphins and turtles in purse seines operating in Indian waters. Bycatch can be minimised by improvement in the net design appropriate for schools of target fishes, mesh size optimisation, use of aprons and operational procedures. Use of dolphin wall net (DWN) on the outer side of the purse seine to reduce the bite of the net by marine mammals has been reported by Prajith et al. (2014). Damage of net by pufferfish has increased over the years, particularly in Kerala (Mohamed et al., 2013). Judicious use of high tenacity fishing gear materials resistant to fish bites like ultra-high molecular weight polyethylene (UHMWPE) may be effective in preventing such damages. During purse seining, there is no impact on the bottom habitat except in shallow water operations, when the lower edge of the gear contacts the sea bottom (Pravin, 2009).

\section{Need for regulations}

The economic returns of purse seining has been decreasing due to overcapacity, fluctuations in the pelagic fishery, escalation in fuel costs, cost of labour and competition for the same resources. In Kerala, for instance, the number of purse seiners has reduced considerably to a meagre 17 in 2004 and most of the purse seiners were converted to trawlers or were lying idle. These units were revived with the introduction of large mesh purse seines for large sized mackerels and other large pelagic fishes which benefitted the fishermen, stakeholders and allied industries by way of employment as well as income generation.

Panikkar et al. (1994) suggested check in purse seining in coastal waters to protect the artisanal fishing and to avoid depletion of pelagic stocks. The optimum fleet size of purse seiners should be 784 units (Kurup and Devaraj, 2000), whereas the present fleet size of purse seiners in the country is 1213 units (CMFRI, 2012). Silas et al. (1980) stressed the need on the regulations for purse seining as there were instances of destructive fishing using purse seine and suggested mesh regulation, restriction on the size of the species caught and delimitation of the areas and periods for operation of purse seine for a specific resource. Dhulkhed et al. (1982) reported that the catfish Tachysurus tenuispinis declined due to the large scale exploitation of male brooders during purse seine operations in Karnataka and stressed the need for regulation of operations during spawning period of the species.

Purse seine operations are relatively energy efficient and greenhouse gas (GHG) emissions for small scale mechanised purse seine operations is low compared to trawling, gillnetting and lining operations (Boopendranath and Hameed, 2013). A significant proportion of the catch of purse seines and ring seines, which includes smaller species, sub-adults and juveniles, are utilised for fish meal production. A recent Technical Committee report has shown concern over the quantity of juveniles in seine catches and highlighted the need for regulations in terms of seasonal fishing ban, prevention of fleet expansion and imposing regulations on vessel capacities $\left(\mathrm{L}_{\mathrm{OA}}\right.$ and $\mathrm{hp}$ ) and gear specifications (length, depth and mesh size) and minimum legal size for harvested species (DAHDF, 2014). Data on bycatch caught in purse seining is deficient and has to be strengthened.

\section{Conclusions}

Adoption of the large mesh purse seine and shifting operations to deeper waters targeting tunas and other large pelagic fishes would ease the fishing pressure in the intensively fished coastal waters. Further, large meshes will facilitate escape of juveniles, as juvenile mortality is a significant issue in purse seining in Indian waters. The fishermen need to be encouraged to go for multiday fishing and operate their nets in deeper waters targeting skipjack tuna, little tuna, carangids, black pomfrets, horse mackerel, barracudas, seerfishes and large sized mackerel, as well as in wider adoption of advanced fish detection and navigation equipments, use of fish aggregation techniques and Potential Fishing Zone (PFZ) information based on remote sensing. Use of power block for hauling the purse seine would further enhance the fishing efficiency, increase the number of sets per day and reduce the drudgery of the crew in hauling the huge purse seine. Measures to alleviate excess fishing capacity, 
regulations on vessel capacities and gear specifications and minimum legal size for harvested species, need to be adopted and implemented. Bycatch in purse seine fisheries in Indian waters has to be studied, as the information is scarce and technological and operational mitigation measures are to be developed, in order to protect non-target species.

\section{References}

Balan, V. 1973. Pursevseine and boat seine (Thangu vala) fishery for the oilsardine off Cochin, 1968-1971. Indian J. Fish., 20(1): 70-77.

Balan, V. and Nizar, M. A. 1988. Purse seine fishery for oilsardine off Cochin during the years 1980-85. Indian J. Fish., 35(3): 70-77.

Balan, V. 1984. The Indian oilsardine fishery: a review. Mar. Fish. Infor. Serv., $T \&$ E. Ser., 60: 1-10.

Ben-Yami, M. 1994a. Purse seining manual. FAO fishing manual. Fishing News Books Ltd., Farnham, 416 pp.

Ben-Yami, M. 1994b. Purse seining with small boats. FAO Training Series 13, FAO, Rome, 97 pp.

Boopendranath, M. R. and Hameed, S. H. 2013. Gross energy requirement in fishing operations, Fish. Technol., 50: 27-35.

Brandt, A. V. 1984. Fish catching methods of the world. Fishing News Books Ltd., London, 432 pp.

Chaniyappa, M. 2009. Bumper landing of giant sea catfish Arius thalassinus by purse seiners at Malpe Fisheries Harbour, Karnataka. Mar. Fish. Infor. Serv, $T$ \&E. Ser., 200: 21.

CMFRI 2014. Annual report 2013-14. Central Marine Fisheries Research Institute, Kochi, 274 pp.

CMFRI 2012. Marine fisheries census 2010 Part-I India, Department of Animal Husbandry, Dairying and Fisheries and ICAR-Central Marine Fisheries Research Institute, Kochi, 2012, 98 pp.

DAHDF 2014. Report of the Technical Committee to Review the duration of the ban period and to suggest further measures to strengthen the conservation and management aspects. Department of Animal Husbandry Dairying and Fisheries, Ministry of Agriculture, New Delhi, 89 pp.

Dhawan, M. R. 1978. Purse seine operations and its prospects in Goa. Abstract No. 7. CMFRI Special Publication, 5.

Dhulkhed, M. H., Hanumantharaya, S. and Channappa, G. N. 1982. Destruction of eggs of catfish. Tachysurus tenuispinis by purse seiners at Karwar. Mar. Fish. Infor. Serv., $T \&$ E. Ser., 44: 16-17.

Edwin, L. and Hridayanathan, C. 1996. Ring seines of south Kerala coast. Fish. Technol., 33(1): 1-5.

Edwin, L., Pravin, P., Madhu, V. R., Thomas, S. N., Remesan, M. P., Baiju, M. V., Renju Ravi, Dhiju Das, P. H. Boopendranath, M. R. and Meenakumari, B. 2014. Mechanized marine fishing systems: India. ICAR-Central Institute of Fisheries Technology, Kochi, 170 pp.
Fyson, J. 1985. Design of small fishing vessels, Fishing News Books Ltd., Farnham, Surrey, England, 319 pp.

Hall, M. and Roman, M. 2013. Bycatch and non-tuna catch in the tropical tuna purse seine fisheries of the world. FAO Fisheries and aquaculture technical paper No. 568. Rome, FAO, 249 pp.

Hameed, M. S. and Asok Kumar, K. 1987. Purse seine fishing in Kerala. Proceedings of the Seminar on Fisheries Research and Development in Kerala, 28 to 29 April 1987, Trivandrum.

Hameed, M. S. and Boopendranath, M. R. 2000. Modern fishing gear technology. Daya Publishing House, Delhi, 186 pp.

Hameed, M. S. and Mukundan, M. 1991. Strategies for the development and management of purse seine fishing in India. CMFRI Special Publication, Part-III, 44: 643-647.

IS:5508. 1975. Indian standard guide for fishing gear, Data sheet for $325 \mathrm{~m}, 350 \mathrm{~m}$ and $450 \mathrm{~m}$ purse seine nets, Part XIV, p. 3-78.

Jacob, T., Alagaraja, K., Dharmaraja, S. K., Panikkar, K. K. P., Balakrishna, G., Satyavan, U. K., Balan, V. and Rao, K. V. N. 1982. Impact of purse seine operations on traditional fishery with special reference to oilsardine in Kerala during 1980-81. Mar. Fish. Infor. Serv., $T \&$ E. Ser., 40: 8-11.

Jadhav, D., G and Chavan, B. B. 2004. Landing of Rachycentron canadum (Linnaeus, 1766) by the purse seines at New Ferry Wharf, Mumbai. Mar. Fish. Infor. Serv., T\& E. Ser., 180: 17.

Jadhav, D. G., Chavan, B. B., Sawanth, A. D., Josekutty, C. J., Sarang, J. D. and Thakurdas. 2004. Unusual landing of Alepes djedaba (Forskal) and Megalaspis cordyla (Linnaeus) by purse seiners at New Ferry Wharf, Mumbai. Mar. Fish. Infor. Serv., $T \&$ E. Ser., 179: 17.

Jadhav, R. R., Mohite, A. S. and Kazi, T. G. 2011. Design and operational characteristics of small meshed purse seine nets with pockets operated off Ratnagiri, Maharashtra. J. Mar. Biol. Ass. India., 53: 237-241.

Jayaraj, M. 1978. Karnataka's breakthrough in diversification of mechanised fishing. Seafood Export J., 10(1): 5-9.

Joice, V. T., Premlal, P. and Kurup, B. M. 2003. The ring seine fishery of Kerala - time to act. Infofish Int., 6: 64-68.

Katkar, B. N., Waghmare, K. B., Chavan, B. B. and Sujit Sundaram 2004. Bumper landing of Arius dussumieri (Valenciennes, 1846) by purse seine net at Sassoon Dock, Mumbai. Mar. Fish. Infor. Serv., T\&E. Ser., 182: 16-17.

Kemparaju, S., Uma, S. B. and Ali, C. G. 1993. A preliminary evaluation of day and night purse seine fishery at Mangalore, Karnataka. Mar. Fish. Infor. Serv., T\& E. Ser., 120: 8-12.

Kemparaju, S., Sreedhara, B., Mahadevaswamy, H. S and Zacharia, P. U. 1992. Unusual landing of catfish by purse seine at Malpe, Dakshina Kannada. Mar. Fish. Infor. Serv., T\& E. Ser., 137: 20 .

KMFRA 1980. Kerala Marine Fisheries Regulation Act (KMFRA), Govt. of Kerla,13 pp. 
Kulkarni, G. M., Balasubramanian, T. S. and Kemparaju, S. 1987. Heavy landing of prawn (Metapenaeus dobsoni) by purse seine at Panaji, Goa. Mar. Fish. Infor. Serv., T\& E. Ser., 71: 17.

Kulkarni, G. M., Kemparaju, S., Mohan, M., Uma, B. and Purandhara, C. 1991. Unusually heavy catch of black pomfret, Formio niger by purse seine along Dakshina Kannada coast. Mar. Fish. Infor. Serv., $T$ \& E. Ser., 114: 34-35.

Kurup, K. N. and Devaraj, N. 2000. Estimates of optimum fleet size for the exploited Indian shelf fisheries, Mar. Fish. Infor. Serv., $T \&$ E. Ser., 165: 2-11.

Mathai, T. J. 1990. Purse seining: A boon or a bane. Seafood Export J., 2: $15-19$.

Meenakumari, B., Pravin, P. and Nikita Gopal 2010. Improved large mesh purse seine for small scale mechanised sector. In: Meenakumari, B., Boopendranath, M. R., Edwin, L., Sankar, T. V., Gopal, N. and Ninan, G. (Eds.), Coastal fishery resources of India: conservation and sustainable utilisation. Society of Fisheries Technologists (India), Kochi, p. 296-304.

Menon, M. D. 1970. Purse seining oil sardines from medium vessels, Souvenir, Central Institute of Fisheries Operatives. p. 28-31.

Mohamed, S. K., Muniyappa, Y., Naik, R. A., Kemparaju, S. and Purandara, C. 1993. An unusual catch of sharks in a purse seine at Malpe. Karnataka. Mar. Fish. Infor. Serv., T\&E. Ser., 121: 10 .

Mohamed, K. S., Sathianandan, T. V., Kripa, V. and Zacharia, P. U. 2013. Pufferfish menace in Kerala: a case of decline in predatory control in the southeastern Arabian Sea. Curr. Sci., 104(4): 426-429.

Mukundan, M. and Hakkim, L. A. 1980. Purse seining - development in Indian waters, Bulletin No. 3, Integrated Fisheries Project, Kochi, p. 1-59.

Mukundan, M., Radhakrishnan, Nair, P., Narayanan, K. P. and Thomas, J. L. 1980. Results of purse seining from $13.27 \mathrm{~m}$ vessels. Seafood Export J., 12(5): 9-17.

Nair, K. V. S. and Jayaprakash, A. A. 1983. Clash between purse seine and artisanal fishermen at Cochin. Mar. Fish. Infor. Serv., $T \&$ E. Ser., 49: 14-16.

Nair, K. V. S and Narayanakutty, V.A. 1985. The Indian white prawn Penaeus indicus in the purse seine catches. Mar. Fish. Infor. Serv., $T \&$ E. Ser., 65: 19.

Nair, K. V. S., Jayaprakash, A. A., Sukumaran, K. K., Telang, K.Y. and Balasubramanian, K. K. 1982. Prawns in purse seine catches. Mar. Fish. Infor. Serv., T \& E. Ser., 42: 9-13.

Nedlec, C. 1982. Definition and classification of fishing gear categories. FAO Fisheries Technical Paper, 222: 1-51.

Oommen, V. P. 1989. A critical study on the exploitation of fishery resources by the Integrated Fisheries Project, Bulletin No. 12, Integrated Fisheries Project, Kochi, p.106.

Panicker, P. A. 1985. An economic analysis of purse seining from $13.25 \mathrm{~m}$ purse seiners and from artisanal fishing craft Thanguvallom along the Kerala coast. In: Ravindran, K.,
Unnikrishnan Nair. N., Perigreen, P. A., Madhavan, P., Gopalakrishna Pillai, A.G., Panicker, P. A. and Mary Thomas (Eds.), Harvest and post harvest technology of fish. Society of Fishery Technologists (India), Kochi, p.173-720.

Panicker, P. A., Sivan, T. M. and George, N. A.1985. A new fishing gear for traditional craft. In: Ravindran, K., Unnikrishnan Nair. N., Perigreen, P. A., Madhavan, P., Gopalakrishna Pillai, A. G., Panicker, P. A. and Mary Thomas (Eds.), Harvest and post harvest technology of fish. Society of Fishery Technologists (India), Kochi, p. 223-226.

Panikkar, K. K. P., Sehara, D. B. S. and Kanakkan, A. 1994. Economic evaluation of purse seine fishery along Goa coast. Mar. Fish. Infor. Serv., T \& E. Ser., 27: 4-8.

Prajith, K. K., Das, P. H. D. and Edwin, L. 2014. Dolphin wall net (DWN)- An innovative management measure devised by ring seine fishermen of Kerala, India to reducing or eliminating marine mammal fishery interactions. Ocean and Coastal Management, 102(Part A): 1-6.

Pravin, P. 2009. Purse seines and their operation. In: Meenakumari, B., Boopendranath, M. R., Pravin, P., Thomas, S. N. and Edwin, L. (Eds.), Handbook of fishing technology. ), ICARCentral Institute of Fisheries Technology, Kochi, p.177-194.

Pravin, P. 2012. Purse seining during night with luring light. Fish Technology Newsletter, 22(3): 3-4.

Pravin, P. and Meenakumari. B. 2011a. Towards the development of eco-friendly purse seines. Infofish International, 6: 50-54.

Pravin, P. and Meenakumari. B. 2011b. Introduction of power block for purse seine operation at Cochin. Fish Technology Newsletter., 22(2): 1-2.

Pravin, P. and Meenakumari, B. 2013a. Purse seine fishing in India. Geography and You, 13(77): 36-42.

Pravin, P. and Meenakumari, B. 2013b. Purse seining in Kerala. Science India, 16(6): 4-10.

Rao, N. K. V., Rao, S. G., Luther, G and Elayathu, M. N. K. 1982. The emerging purse seine fishery for anchovy (whitebait) resources of the west coast of India. Mar. Fish. Infor. Serv., $T \&$ E. Ser., 36: 1-6.

Sadanandan, K. A., Kunjipalu, K. K., George, N. A. and Mathai, T. J. 1975. Purse seines off Goa. Fish. Technol., 12(1): 45-51.

Sainsbury, J. C., 1996. Commercial fishing methods - An introduction to vessels and gear. Fishing News Books Ltd., Farnham, $352 \mathrm{pp}$.

Shanmugavelu, C. R. and Pillai, P. K. M. 1980. On the results of exploratory purse seining between Cochin and Goa. Indian J. Fish., 27(1-2): 183-192.

Shiledar, B. A. A. 2009. A new gear 'mini purse seine' in MH-1 zone of Maharastra coast. Mar. Fish. Infor. Serv., T. \& E. Ser., 200: 4.

Silas, E. G. 1969. Exploratory fishing by R.V. Varuna, Bull. Cent. Mar. Fish. Res. Inst., 12: 86.

Silas, E. G., Pillai, P. P., Dhulked, M. H., Muthiah, C. and Rao, G. S. 1980. Purse seine fishery - imperative and regulation. Mar. Fish. Infor. Serv., T\& E. Ser., 24: 1-9. 
Sukumaran, K. K. 1993. The prawn fishery of the south Kanara coast with emphasis on the unusual catches of Metapenaeus dobsoni by purse seines and trawls during the first half of September, Mar. Fish. Infor. Serv., T \& E. Ser., 65: 1-7.

Udaya, V. A. 2004. Unusual heavy landing of white prawn, Penaeus indicus by purse seiners at Gangoli Fisheries Harbour, Udupi District, Karnataka. Mar. Fish. Infor. Serv., $T \&$ E. Ser., 180: $17 \mathrm{pp}$.
Verghese, C. P. 1973. Purse seining, Indian Seafoods, (10)1: 12-15.

Verghese, C. P. 1976. Introduction of purse seine fishing in Indian coasts - operation from 36' and 57' vessels for sardine and mackerel, Seafood Export J., 8(1): 11-21.

Zacharia, P.U., Nagaraja, D. and Muniyappa, Y. 1991. On the regular landing of tongue sole by purse seiners at Mangalore and Malpe, Karnataka coast. Mar. Fish. Infor. Serv., $T \& E$. Ser., 108: 4-15. 